\title{
Education Quality and Student Satisfaction in Private Universities: An Empirical Study of FPT University Da Nang, Vietnam
}

\author{
Van Ky Long Nguyen*, Thi My Hanh Le, Thi Minh Chau Tran, Thi Hien Le, Thi Thu Hien Le, \\ Nhu Hoa Vo
}

Faculty of Business, FPT University, Vietnam

Received February 9, 2021; Revised March 29, 2021; Accepted May 10, 2021

Cite This Paper in the following Citation Styles

(a): [1] Van Ky Long Nguyen, Thi My Hanh Le, Thi Minh Chau Tran, Thi Hien Le, Thi Thu Hien Le, Nhu Hoa Vo, "Education Quality and Student Satisfaction in Private Universities: An Empirical Study of FPT University Da Nang, Vietnam," Universal Journal of Educational Research, Vol. 9, No. 6, pp. 1148-1161, 2021. DOI: 10.13189/ujer.2021.090604.

(b): Van Ky Long Nguyen, Thi My Hanh Le, Thi Minh Chau Tran, Thi Hien Le, Thi Thu Hien Le, Nhu Hoa Vo (2021). Education Quality and Student Satisfaction in Private Universities: An Empirical Study of FPT University Da Nang, Vietnam. Universal Journal of Educational Research, 9(6), 1148-1161. DOI: 10.13189/ujer.2021.090604.

Copyright $\mathrm{C} 2021$ by authors, all rights reserved. Authors agree that this article remains permanently open access under the terms of the Creative Commons Attribution License 4.0 International License

\begin{abstract}
The current world is in a period of remarkably rapid development of the world economy, which requires timely educational thinking innovation or else will quickly fall behind. Currently, education is a matter of deep concern, not only for experts in the industry but also for students who are directly studying at the university. Additionally, education has recently changed into a service business and adapted to private universities. However, since private universities are not granted much funding from the state, unlike their public counterparts, there are several pressing obstacles that the private institutions have to face, such as advancing the quality of services and achieving students' satisfaction to attract more customers and investors. This tendency has led to significant demands for a structural, comprehensive, and specific approach to measuring the standard of service delivery. Therefore, this study is released to offer an advanced and more specific approach to assessing the quality of university training through the Service-Product Bundle model, along with providing the integrated model to calculate the level of student satisfaction with education quality and identifying the essential factors that affect the student satisfaction. Besides, since there are not many assessments that have been done in private universities, this study proposes to investigate the state of private education quality. The research results reveal that there are five components affecting student satisfaction, namely
\end{abstract}

tuition, lecturers, serviceability, education program, infrastructure respectively. Accordingly, by detecting weaknesses, inadequacies in the learning process, the authors then contribute a basis for proposing implications and recommendations to managers of private universities in general, and FPT University Da Nang in detail, to address problems and outline the timely strategies, yet amend student satisfaction with the quality of education.

Keywords Student Satisfaction, Education Quality, Private Universities, FPT University

\section{Introduction}

Education is considered a prominent branch of a country, as it plays a core role in the training of high-quality human resources who will contribute to the long-term development of the country, as long as becoming the fundamental contribution to national economic prosperity. Formerly, education was viewed as a non-profit human training career activity. However, under the impact of foreign influences, especially the effect of the market economy, it has recently been seen as an "educational service" in which customers (students, parents) can invest and choose the best fit service providers (schools) that can meet their needs [1]. This tendency has led to the existence 
of private universities as a concept. On the contrary to public universities, which are in state ownership or receive significant public funds through a national or subnational government, private universities are not granted much funding from the state. However, since "university tuition typically remains constant throughout the years of enrollment while delayed degree completion is increasingly a problem for academic institutions around the world" [2], several obstacles are threateningly challenging the private institutions compared to the public universities. Accordingly, student satisfaction is becoming a core component of the universities' marketing strategy during the harsh period of the diminishing number of prospective undergraduates and the intense competition. Therefore, by taking care of their operating expenses, private institutions in higher education are regularly enhancing the school performances and the quality of education, to attract, maintain, and foster students by achieving their satisfaction, therefore maximizing the profits in an increasingly competitive environment. Simultaneously, these operations also advance the opinions and perspectives of students about their academic experience, which is being constantly surveyed and examined by service providers in private universities. Thus, the demand for a structural, comprehensive, and specific approach to assessing the private education quality and customer satisfaction in service delivery is often a pressing concern.

In recent years, FPT Education has come to be a famous private education in Vietnam. FPT University is the first university set up by an enterprise in Vietnam and becomes a modern philosophy combination between local and international. In 2012, FPT University became the first university in Vietnam to be awarded a 3-star ranking by the QS World University Ranking System - one among three of the most well-known university ranking systems worldwide, in which Teaching Quality and Social Engagement were ranked five stars [3]. In the next few years, FPT Education remains to achieve admirable standard achievement in every faculty such as ASOCIO's 2018 Outstanding ICT training unit award by Asian-Oceanian Computing Industry Organization and the quality of business administration training by international education quality standards ACBSP in 2019 [4]. The FPT University Da Nang Campus, one of the branches of FPT University, invariably has a consistent training quality system with the main campus (Hoa Lac Campus). FPT University is one of the largest private schools in Vietnam with more than 23,000 students and several awards being given. Therefore, FPT University can acceptably represent the private school system in Vietnam. Although FPT University has gained various outstanding achievements related to teaching quality in the past few years, FPT University is still obliged to maintain the quality of education as noble as possible. In contrast, although FPT University has made a lot of effort in advancing the quality of education, it has yet to gain enormous recognition from the Vietnam education market. To enhance the image of
FPT University education quality, the research is conducted to provide a comprehensive overview of education quality at private universities, especially in FPT University, along with the deficiencies and shortcomings. Accordingly, the director of FPT Education can utilize this study to acknowledge the weaknesses and strengths in the education system. Furthermore, the other private universities in Vietnam can adopt the research of FPT University as the case study to reflect their education quality.

In this research, we provide a distinctive approach to evaluate the level of student satisfaction with education quality. While many pieces of research use the SERVQUAL model (Parasuraman, 1988) to value the degree of student satisfaction, our research adopts the concept of the Service-Product Bundle model. This transformation is due to one particular deficiency of the SERVQUAL model: the dimensions it sets as the foundation are not universals, despite the apparent complexity of student satisfaction in higher education. Therefore, by acknowledging the problem, our survey questionnaire is designed based on the Service-Product Bundle model, which provides a more comprehensive range of variables that precisely affect student satisfaction in higher education. Based on the survey of 159 students from Oct 30 to Nov 4, the study aims to provide an overview of the promising factors which can be used to evaluate student satisfaction with the quality of higher education. Accordingly, it provides the universities' administrators with several conceivable directions to advance the performances of the institution by pointing out the deficiencies and inadequacies in the learning process. The paper begins by introducing the descriptions of some key terms and reviewing the literature on service in higher education. Then, it describes the Service-Product Bundle method to develop a distinct model measuring the primary attributes in higher education preferred. By implementing this measurement model, the study uncovers the constructs and in-depth analysis that underlines student satisfaction. It also concludes with a summary of findings and suggestions for future research. The results of this research reveal that there are five factors affecting student satisfaction of private universities, which are sorted in the decreasing order of impact: Tuition, Lecturers, Education Program, Infrastructure and Serviceability.

\section{Theoretical Background and Research Framework}

\subsection{Theoretical Background}

\subsubsection{Education Quality}

Service quality is an extensive and complex field, which reflects the synthesis of economic, technical and social content. According to Kotler and Keller (2009), the meaning of service is "A service is an act of performance 
that one party can offer to another that is essentially intangible and does not result in the ownership of anything" [5]. In terms of service quality, Lewis and Booms (1983) have implied that "Service quality is a measure of how well the service level delivered matches customer expectations" [6].

Education is also an essential part of the service. According to Tho and Trang (2009): "Education is a service, a commodity that is both collective (decided by the state and the public) and market (decided by the market)" [7]. Education also has "the simultaneous production and consumption, requiring the participation of the customer", which is reasonable to be classified into the service field. [8].

There are diverse conceptualizations of quality in use (Schuller, 1991). Since there are a variety of 'stakeholders' in higher education, namely students, employers, teaching and non-teaching staff, government and its funding agencies, etc. (Burrows and Harvey, 1992) [9], the concept of "quality of education" is a definition that is "difficult to define and measure, because there isn't a consistent definition" (Cheng and Tam, 1997) [6].

However, the quality of training as defined by Harvey and Green (1994) is mainly from the assessment of the experts: "The focus of attention for students and lecturers might be on the process of education while the focus of employers might be on the outputs of higher education" [9]. Therefore, O'Neill and Palmer (2004) depicted the education quality as "the difference between what a student expects to receive and his/her perceptions of actual delivery" [10].

\subsubsection{Student satisfaction}

The satisfaction of customers has been defined in many ways. As claimed by Oliver (1985), the satisfaction is depicted as "the consumers' satisfaction in consuming a product or service as it fulfils their wishes, including the level of response above the desired level and below the desired level" [11]. Accordingly, Tse and Wilton (1988) described the satisfaction as "the reaction of the customers on the difference between the desire and the feeling after using the service" [12]. Meanwhile, according to Kotler (2012), the satisfaction is "the degree of one's sensory state resulting from a comparison of results obtained from the service with the person's expectations." [13].

Although there are various depictions about satisfaction, all of them often lead to one single point: meeting the expectations, desires, or wishes of customers. Student satisfaction has exhibited such traits in a higher education environment. According to Borden (1995), student satisfaction is associated with the match between student priorities and the campus environment [14]. It is "a short-term attitude resulting from an evaluation of a student's educational experience" and occurs when "actual performance meets or exceeds" his or her expectations [15].

Overall, the satisfaction of students can be defined as the compatibility between their expectations and the performance of educational experience, services and infrastructure.

\subsection{Theoretical Framework}

There are a variety of previous studies that utilized the SERVQUAL model (Parasuraman 1988) to measure service quality in higher education with student perceptions. However, its applications in higher education have met with little success and been criticized throughout the years (see, for example, Waugh, 2002; Buttle, 1996; Asubonteng et al, 1996; Pariseau and McDaniel, 1997) [16-19].

Thus, we base on the Service-Product Bundle model of Jacqueline Douglas, Alex Douglas and Barry Barnes [20] as it gives an extensive range of 12 dimensions [21] affecting student satisfaction in higher education. The scope of this model is more comprehensive and specific to investigate service quality in higher education, compared to SERVQUAL with only 10 dimensions. The Service-Product Bundle model provides 12 dimensions in total [21], which are categorized into four variables [20]:

Table 1. The Service-Product Bundle model

\begin{tabular}{|c|c|c|}
\hline VARIABLE & DIMENSIONS & EXAMPLES \\
\hline $\begin{array}{l}\text { The facilitating } \\
\text { goods }\end{array}$ & $\begin{array}{ll}\text { - } & \text { Lecture and tutorial facilitating goods } \\
\text { - } & \text { Textbooks. }\end{array}$ & $\begin{array}{l}\text { The lectures and tutorials, presentation slides, supplementary } \\
\text { handout materials and the recommended module text }\end{array}$ \\
\hline $\begin{array}{l}\text { The physical } \\
\text { facilities }\end{array}$ & $\begin{array}{ll}- & \text { Student support facilities } \\
\text { - } & \text { Professional and comfortable } \\
\text { environment } \\
\text { - } \quad \text { Classroom environment } \\
\text { Class sizes }\end{array}$ & $\begin{array}{l}\text { The lecture theatres and tutorial rooms and their level of } \\
\text { furnishing, decoration, lighting and layout as well as ancillary } \\
\text { services. }\end{array}$ \\
\hline $\begin{array}{l}\text { The explicit service } \\
\text { (the sensual service } \\
\text { provided) }\end{array}$ & $\begin{array}{l}\text { - Knowledgeable and responsiveness of } \\
\text { faculty } \\
\text { - } \quad \text { Business procedures } \\
\end{array}$ & $\begin{array}{l}\text { The knowledge levels of staff, staff teaching ability; the } \\
\text { consistency of teaching quality irrespective of personnel; the level } \\
\text { of difficulty of the subject content and the workload }\end{array}$ \\
\hline $\begin{array}{l}\text { The implicit service } \\
\text { (the psychological } \\
\text { service provided) }\end{array}$ & $\begin{array}{l}\text { - Student assessments and learning } \\
\text { experiences } \\
\text { - } \quad \text { Relationship with teaching staff } \\
\text { - } \quad \text { Staff helpfulness } \\
\text { - Feedback }\end{array}$ & $\begin{array}{l}\text { The treatment of students by staff; the ability of the university's } \\
\text { environment to make the student feel comfortable; the sense of } \\
\text { competence, confidence and professionalism conveyed by the } \\
\text { ambiance in lectures and tutorials, feeling that the student's best } \\
\text { interest is being served and a feeling that rewards are consistent } \\
\text { with the effort put into coursework and examinations. }\end{array}$ \\
\hline
\end{tabular}

The relationship between education quality and student satisfaction has been proved through a lot of research. 
Table 2. The literature review of articles

\begin{tabular}{|c|c|c|c|c|c|c|c|}
\hline \multirow{2}{*}{ No } & \multirow{2}{*}{ AUTHOR } & \multirow{2}{*}{ YEAR } & \multirow{2}{*}{ RESEARCH } & \multirow{2}{*}{ VARIABLE } & \multirow{2}{*}{ DEFINITION } & \multicolumn{2}{|c|}{ RESULT } \\
\hline & & & & & & Positive & Negative \\
\hline 1 & Pham Thi Lien & 2016 & $\begin{array}{l}\text { Training Quality and Student } \\
\text { Satisfaction } \\
\text { The Case of VNU University of } \\
\text { Economics and Business [1] }\end{array}$ & $\begin{array}{l}\text { 1. Facilities } \\
\text { 2. Education Program } \\
\text { 3. Lecturer } \\
\text { 4. Ability to serve }\end{array}$ & $\begin{array}{l}\text { 1. Facilities: External facilities (classrooms, teaching } \\
\text { equipment, teaching materials, learning materials, etc.) } \\
\text { 2. Education Program: Training objectives, output } \\
\text { standards of training programs, training plans with } \\
\text { subjects in the program, etc. } \\
\text { 3. Lecturer: Teachers' knowledge, experience, and } \\
\text { understanding with students. } \\
\text { 4. Serving Ability: Capacity and quality of the student } \\
\text { service of support staff }\end{array}$ & $\begin{array}{l}\text { 1. Education } \\
\text { program } \\
\text { 2. Facilities } \\
\text { 3. The ability to } \\
\text { serve }\end{array}$ & Lecturer \\
\hline 2 & Tran Huu Ai & 2016 & $\begin{array}{l}\text { Application of structural } \\
\text { equation modeling to examine } \\
\text { the relationship between } \\
\text { educational } \\
\text { quality and student feeling of } \\
\text { satisfaction: a case study of the } \\
\text { Faculty of Economic at VHU } \\
\text { [22] }\end{array}$ & $\begin{array}{l}\text { 1. Teacher Quality } \\
\text { 2. Facilities and Equipment } \\
\text { 3. Trust (from school) } \\
\text { 4. Education Program } \\
\text { 5. Educational } \\
\text { Environment }\end{array}$ & $\begin{array}{l}\text { 1. Teacher Quality: According to the encyclopedia of the } \\
\text { Vietnam Academy of Sciences, the teacher is the one who } \\
\text { does the teaching work in the universities, colleges and } \\
\text { training classes. } \\
\text { 2. Facilities and Equipment: All material means are } \\
\text { mobilized for teaching, learning and other educational } \\
\text { activities to achieve educational purposes. } \\
\text { 3. Reliability (from school): The ability to perform } \\
\text { exactly what has been committed and promised about } \\
\text { learning conditions, learning policies and the school's } \\
\text { curriculum. } \\
\text { 4. Education Program: Including content structure of } \\
\text { subjects, training time, time distribution ratio between } \\
\text { basic and specialized subjects, between theory and } \\
\text { practice } \\
\text { 5. Educational Environment: All physical and mental } \\
\text { conditions in which people learn, live, work and study, are } \\
\text { used to affect the formation of the suitable student's } \\
\text { personality for prescribed educational purposes. }\end{array}$ & $\begin{array}{l}\text { 1. Facilities } \\
\text { 2. Teacher Quality } \\
\text { 3. Education } \\
\text { Program } \\
\text { 4. Educational } \\
\text { Environment }\end{array}$ & $\begin{array}{l}\text { Trust } \\
\text { school) }\end{array}$ \\
\hline 3 & $\begin{array}{l}\text { Hoang Thanh } \\
\text { Huyen, } \\
\text { Tran Thi Thai } \\
\text { Ha }\end{array}$ & 2019 & $\begin{array}{l}\text { A survey on the level of student } \\
\text { satisfaction of the training } \\
\text { quality of the accounting - } \\
\text { auditing faculty at Banking } \\
\text { Academy of Vietnam [23] }\end{array}$ & $\begin{array}{l}\text { 1. Education Program } \\
\text { 2. Lecturers } \\
\text { 3. Facilities } \\
\text { 4. Serving Quality } \\
\text { 5. Tuition Fees }\end{array}$ & $\begin{array}{l}\text { 1. Education Program } \\
\text { 2. Lecturers } \\
\text { 3. Facilities } \\
\text { 4. Serving Quality } \\
\text { 5. Tuition Fees } \\
\text { - In accordance with the actual conditions of the students, } \\
\text { the authors propose to add the Tuition factor because this } \\
\text { is a decisive factor to the choice of students when } \\
\text { attending university. }\end{array}$ & $\begin{array}{l}\text { 1. Education } \\
\text { Program } \\
\text { 2. Lecturers } \\
\text { 3. Tuition Fees } \\
\text { 4. Facilities }\end{array}$ & Ability to serve \\
\hline
\end{tabular}


Table 2 Continued

\begin{tabular}{|c|c|c|c|c|c|c|c|}
\hline 4 & $\begin{array}{l}\text { Nguyen Thanh } \\
\text { Long }\end{array}$ & 2006 & $\begin{array}{l}\text { Using the SERVPERF } \\
\text { scale to assess the } \\
\text { education quality of An } \\
\text { Giang University } \\
\text { [24] }\end{array}$ & $\begin{array}{l}\text { 1. Lecturer } \\
\text { 2. Employees } \\
\text { 3. Facilities } \\
\text { 4. Reliability (from school) } \\
\text { 5. Empathy (from school) }\end{array}$ & $\begin{array}{l}\text { 1. Lecturer } \\
\text { 2. Employees } \\
\text { 3. Facilities: a physical representation of facilities, } \\
\text { equipment, staff and materials, information tools. } \\
\text { 4. Reliability (from school): the ability to perform } \\
\text { the service in accordance and exactly with what is } \\
\text { committed and promised. } \\
\text { 5. Empathy (from school): showing kindness and } \\
\text { attention to each customer. }\end{array}$ & 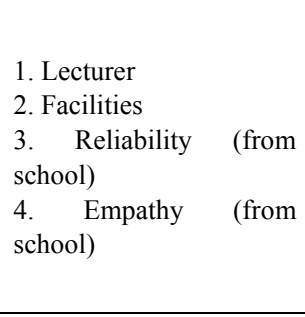 & Staff \\
\hline 5 & $\begin{array}{l}\text { Nguyen Thi } \\
\text { Bao Chau, } \\
\text { Thai Thi Bich } \\
\text { Chau }\end{array}$ & 2013 & $\begin{array}{l}\text { Assessing the level of } \\
\text { student satisfaction with } \\
\text { the quality of training of } \\
\text { the school of economics - } \\
\text { business administration at } \\
\text { Can Tho University a } \\
\text { period of years 2012-2013 } \\
\text { [25] }\end{array}$ & $\begin{array}{l}\text { 1. Staff Attitude } \\
\text { 2. Teacher's Ability } \\
\text { 3. Facilities } \\
\text { 4. Staff Attire and Course } \\
\text { Information } \\
\text { 5. Libraries } \\
\text { 6. Work Area, Information } \\
\text { Technology Application }\end{array}$ & & $\begin{array}{l}\text { 1. Teacher's Behavior } \\
\text { and Ability } \\
\text { 2. Facilities }\end{array}$ & $\begin{array}{l}\text { 1. Staff's } \\
\text { Behavior and } \\
\text { Attitude } \\
\text { 2. Staff Attire } \\
\text { and Course } \\
\text { Information } \\
\text { 3. Libraries } \\
\text { 4. Work Area, } \\
\text { Information } \\
\text { Technology } \\
\text { Application }\end{array}$ \\
\hline 6 & $\begin{array}{l}\text { Nguyen Thi } \\
\text { Ngoc Xuan }\end{array}$ & 2018 & $\begin{array}{l}\text { Factors affecting student } \\
\text { satisfaction with the } \\
\text { quality of education quality } \\
\text { at Tra Vinh University [26] }\end{array}$ & $\begin{array}{l}\text { 1. Access to Education Services } \\
\text { 2. Facilities } \\
\text { 3. Educational Environment } \\
\text { 4. Educational Activities } \\
\text { 5. Education Outcomes }\end{array}$ & $\begin{array}{l}\text { 1. Access to Education Services: the enthusiasm of } \\
\text { faculty staff (teachers) as well as the level of } \\
\text { willingness to respond and provide services to } \\
\text { students on time } \\
\text { 2. Facilities: tangible facilities such as equipment, } \\
\text { lecture halls, libraries } \\
\text { 3. Educational Environment: educational } \\
\text { environment means physical and mental conditions } \\
\text { affecting educational, learning, training and } \\
\text { development activities of students. } \\
\text { 4. Educational Activities: Educational activities: } \\
\text { knowledge, expertise, teaching activities, staff's } \\
\text { enthusiasm and ability to make students entrust } \\
\text { 5. Education Outcomes: the quality products that } \\
\text { universities create in the training process that can } \\
\text { meet the students' expectations and social needs. }\end{array}$ & $\begin{array}{l}\text { 1. Education Outcomes } \\
\text { 2. Educational Activities } \\
\text { 3. Educational } \\
\text { Environment } \\
\text { 4. Facilities } \\
\text { 5. Access to Education } \\
\text { Services }\end{array}$ & \\
\hline
\end{tabular}


Table 2 Continued

\begin{tabular}{|c|c|c|c|c|c|c|}
\hline 7 & $\begin{array}{c}\text { Nguyen Thi } \\
\text { Xuan Huong, } \\
\text { Nguyen Thi } \\
\text { Phuong, } \\
\text { Vu Thi Hong } \\
\text { Loan } \\
\end{array}$ & 2016 & $\begin{array}{l}\text { Factors affecting students' } \\
\text { satisfaction with conditions } \\
\text { of the facilities and } \\
\text { services of Vietnam } \\
\text { National University of } \\
\text { Forestry (VNUF) [27] }\end{array}$ & $\begin{array}{l}\text { 1. Facilities } \\
\text { 2. Serving Ability } \\
\text { 3. Care/ Empathy } \\
\text { 4. Responsiveness } \\
\text { 5. Reliability }\end{array}$ & $\begin{array}{l}\text { 1. Facilities } \\
\text { 2. Reliability } \\
\text { 3. Responsiveness } \\
\text { 4. Serving Ability } \\
\text { 5. Care / Empathy }\end{array}$ & \\
\hline 8 & $\begin{array}{l}\text { Nguyen Quoc } \\
\text { Nghi, } \\
\text { Nguyen Thi } \\
\text { Bao Chau, } \\
\text { Pham Ngoc } \\
\text { Giao }\end{array}$ & 2012 & $\begin{array}{l}\text { Factors affecting the level } \\
\text { of student satisfaction with } \\
\text { the quality of tourism } \\
\text { training among universities } \\
\text { in the Mekong Delta [28] }\end{array}$ & $\begin{array}{l}\text { 1. OTJ Conditions } \\
\text { 2. Social Knowledge } \\
\text { 3. Lecturer's Interaction } \\
\text { 4. Improvement of Foreign } \\
\text { Language Skills }\end{array}$ & $\begin{array}{l}\text { 1. Lecturer's } \\
\text { Interaction } \\
\text { 2. OTJ Conditions } \\
\text { 3. Improvement of } \\
\text { Foreign Language } \\
\text { Skills } \\
\text { 4. Social Knowledge }\end{array}$ & \\
\hline 9 & Vo Van Viet & 2017 & $\begin{array}{l}\text { Factors affecting student } \\
\text { satisfaction with the } \\
\text { education quality: A } \\
\text { survey from alumni of } \\
\text { Nong Lam } \\
\text { University [29] }\end{array}$ & $\begin{array}{l}\text { 1. Education Program } \\
\text { 2. Lecturer } \\
\text { 3. Extracurricular Activities } \\
\text { 4. Learning Support Services }\end{array}$ & $\begin{array}{l}\text { 1. Learning Support } \\
\text { Services } \\
\text { 2. Education Program } \\
\text { 3. Lecturer } \\
\text { 4. Extracurricular } \\
\text { Activities }\end{array}$ & \\
\hline 10 & $\begin{array}{c}\text { Ha Nam } \\
\text { Khanh Giao, } \\
\text { Tran Thi My } \\
\text { Van }\end{array}$ & 2020 & $\begin{array}{l}\text { The satisfaction of students } \\
\text { with the quality of basic } \\
\text { science courses taught by } \\
\text { Saigon Technology } \\
\text { University [30] }\end{array}$ & $\begin{array}{l}\text { 1. The Course Tuition } \\
\text { 2. Lecturer } \\
\text { 3. Education Program } \\
\text { 4. Facilities } \\
\text { 5. Support Team } \\
\end{array}$ & $\begin{array}{l}\text { 1. The Course Tuition } \\
\text { 2. Lecturer } \\
\text { 3. Education Program } \\
\text { 4. Facilities }\end{array}$ & $\begin{array}{c}\text { Support } \\
\text { Team }\end{array}$ \\
\hline
\end{tabular}




\subsection{Proposed Research Framework}

According to the literature review on ten pieces of research about the elements affecting the student satisfaction with the education quality, along with the Service-Product Bundle model, we then introduce an integrated framework to survey the student satisfaction based on the results of those papers.

Besides, since there is the absence of tangible evidence on which to evaluate quality, customers must depend on other signs. The nature of these other ideas has not been investigated by the scientists, however, some authors have suggested that "price becomes a crucial quality indicator in situations where other information is not available" (McConnell 1968, Olander 1970, Zeithaml 1981) [31]. The relationship of quality with cost-effectiveness has given new meaning to the analysis of quality in higher education. Hence, we add the factor "Tuition" to examine student satisfaction thoroughly.

Based on the theoretical analysis and previous studies, several definitions and hypotheses for the components are given as:

\subsubsection{Infrastructure $(\mathrm{H} 1)$}

Infrastructure will positively affect student satisfaction with the education quality.

In terms of several institutions, infrastructure factors are perceived to have an essential influence on students' choice of universities [32]. Infrastructure can be defined as "all of the physical representation of infrastructures that serves the teaching, learning and other educational activities to achieve educational purposes" [22, 24]. It includes equipment in classrooms, classroom quality, library quality and online learning applications. In this research, we propose that there is a positive relationship between the infrastructure dimension of education quality and student satisfaction.

\subsubsection{Lectures $(\mathrm{H} 2)$}

Lecturers will positively affect student satisfaction with the education quality.

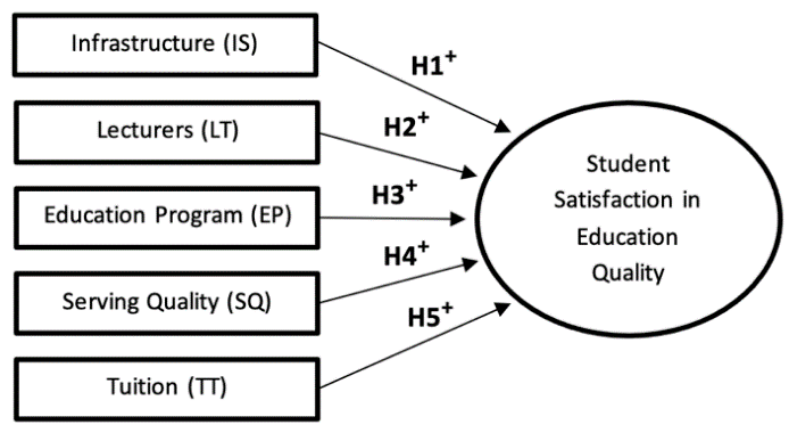

Figure 1. Model of the student satisfaction with education quality

Lecturers can be described as "the person who does the teaching work in the universities, colleges and training classes" [22]. It involves qualifications, knowledge and experience, teaching methods, punctuality, responsiveness and enthusiasm. The lecturer is one of the vital elements that affect the level of student satisfaction. Accordingly, the perceptions of a caring, supportive relationship with a teacher and a positive classroom environment are effectively related to school satisfaction [33]. In this research, we suggest that there is a positive relationship between the lecturer's dimension of education quality and student satisfaction.

\subsubsection{Education Program (H3)}

Education program will positively affect student satisfaction with the education quality.

Education programs are also acknowledged as one of the elements influencing the education quality perceived by students. It is determined as "a group of related courses, written to attain specific educational objectives of the university" [34], which comprises the syllabus, learning materials, outcome standard, timely and sufficient notification, the combination of theory and practice of the curriculum, extra-activities, social and practical skills. In this study, we propose that there is a positive relationship between the education program dimension of education quality and student satisfaction.

\subsubsection{Service quality $(\mathrm{H} 4)$}

Service quality will positively affect student satisfaction with the education quality.

Service quality is considered to be a requisite factor needed in any service activity. It is "the ability and quality of the staff to support students and maximize the students' experience, the enthusiasm of faculty staff (teachers) as well as the level of willingness to respond and provide services to students on time" [26]. The ability of serving can be classified as the service attitude, resolution responsibilities, speed of updating information and providing services, internship program. In terms of service quality, we recommend that there is a positive relationship between the service quality dimension of education quality and student satisfaction.

\subsubsection{Tuition (H5)}

Tuition will positively affect student satisfaction with the education quality.

Several studies indicate that tuition is "associated with improved examination performance and enhanced access to tertiary education" [35], therefore it can considerably affect the level of student satisfaction. Tuition is "the money one must pay during a whole university period including an educational program and development personal activities" [36]. It can be measured as the suitability of infrastructure, quality of education, and quality of service. Accordingly, we suggest that there is a positive relationship between the facilities dimension of education quality and student satisfaction. 


\section{Materials and Methods}

The research process includes two stages:

- Starting with Qualitative research. The survey is designed to collect data from students. Simultaneously, a scale concept is also chosen, which has to be easy for the respondents to comprehend and rapidly answer the questions. After that, the variable effects will be observed and adjusted to match the observation in reality.

- The second stage is Quantitative research, which focuses on examining the collected data. Firstly, the correlated degree of the questionnaires is tested by using Cronbach's Alpha Coefficients. Additionally, the Exploratory Factor Analysis (EFA) method is used to determine the groups of factors of education quality. Lastly, Correlation Analysis and Multiple Regression Analysis are employed to analyze five primary factors that affect student satisfaction.

\subsection{Data Collection}

The data is collected through the survey, which is designed to collect students' assessments on the education quality at FPT University Da Nang and the satisfaction level that they have experienced. The fundamental part of the questionnaire consists of 22 observable variables belonging to five factors, namely Infrastructure, Lecturers,
Education Program, Tuition and Service Quality (Table 3). Accordingly, with the questionnaire of 22 observed variables, the study requires to collect a minimum sample size of 110 samples. Therefore, online questionnaires are sent to all students of different faculties, and this process has lasted for 6 days, from Oct 30 to Nov 4. After this process, we have collected 167 forms, and get 159 results after excluding 18 invalid votes.

\subsection{Measurement Instrument}

The variables are measured by the 5-degree Likert Scale, which uses a sequence of questions with five distinctive answers: totally disagree (1), disagree (2), neutral (3), agree (4), and totally agree (5) [37]. The particular explanation to the variables is merged so that individuals with the disapproving attitudes will get the lowest scores, and individuals with the most approving attitudes will get the highest scores [38]. The Likert Scale is considered to be the most well-known method for survey collection because of its advantages. It can collect data instantly from large numbers of respondents, and make a highly reliable estimate of a person's ability. Moreover, the rationality of interpretations made from the data can be set up via plenty of means, and the data provided can be contrasted, compared and merged with qualitative data collection techniques, such as interviews, open-ended questions and participant observations [39].

Table 3. Indicators measuring education quality

\begin{tabular}{|c|c|c|}
\hline Component & Observable variables & Symbol \\
\hline \multirow{4}{*}{$\begin{array}{l}\text { Infrastructure } \\
\text { (IS) }\end{array}$} & Modern equipment can ensure the conditions for meeting the learning needs of students & IS1 \\
\hline & The library ensures space and references to meet the learning and research needs of students & IS2 \\
\hline & The syllabus and learning materials for each subject are offered fully & IS3 \\
\hline & Online effective utility applications are equipped for effective teaching and learning & IS4 \\
\hline \multirow{4}{*}{$\begin{array}{l}\text { Lecturers } \\
\quad \text { (LT) }\end{array}$} & Lecturers are highly qualified and have extensive knowledge of their teaching expertise & LT1 \\
\hline & The teaching method of lecturers helps students easily grasp the lesson content & LT2 \\
\hline & Lecturers ensure class time and instructional plan & LT3 \\
\hline & Lectures are friendly and willing to answer questions from students & EP4 \\
\hline \multirow{3}{*}{$\begin{array}{c}\text { Education } \\
\text { program } \\
\text { (EP) }\end{array}$} & The education program has clear output standards & EP1 \\
\hline & The education program is fully informed to students & EP2 \\
\hline & The education program is a combination of theory and practice & EP3 \\
\hline \multirow{4}{*}{$\begin{array}{l}\text { Service quality } \\
\text { (SQ) }\end{array}$} & The managers have a good service attitude and listen to students' opinions & EP1 \\
\hline & The managers assist and satisfy the students' requests & SA2 \\
\hline & Information on the website is constantly updated & SA3 \\
\hline & The university ensures internships for students & SA4 \\
\hline \multirow{3}{*}{$\begin{array}{c}\text { Tuition } \\
\text { (TT) }\end{array}$} & Tuition is consistent with the quality of facilities & TT1 \\
\hline & Tuition is consistent with the quality of education & TT2 \\
\hline & Tuition is consistent with the quality of service & TT3 \\
\hline \multirow{4}{*}{$\begin{array}{l}\text { Satisfaction } \\
\quad \text { (SF) }\end{array}$} & The education program meets students' personal expectations & SF1 \\
\hline & $\begin{array}{l}\text { Knowledge gained from the curriculum helps students to be confident in their ability to find a } \\
\text { job after graduation }\end{array}$ & SF2 \\
\hline & Lecturers provide the best support for students learning needs & SF3 \\
\hline & Are you satisfied with the education quality of Da Nang FPT University & SF4 \\
\hline
\end{tabular}




\subsection{Analytical Procedures}

Firstly, we work on SPSS software to process the data through several factors. The data analysis process conveys descriptive statistics and the evaluation of the reliability of the scale by using Cronbach's Alpha Coefficients, Exploratory Factor Analysis (EFA), Correlation and Multiple Regression Analysis. Cronbach's Alpha reliability coefficient is used to estimate the reliability of independent factors, EFA method is used to determine the groups of factors of education quality. Besides, the Multiple Regression method is for evaluating the level and the importance of factors, along with providing the most suitable equation with the observed results of the dependent variable and the independent variable. Meanwhile, Correlation is for determining the correlation between the independent variables and the dependent variables. Ultimately, we investigate five leading factors influencing student satisfaction, including Infrastructure, Lecturers, Education Program, Tuition and Service Quality.

\section{Research Results}

\subsection{Overview of the Research Sample}

After surveying, we have collected 167 forms, and get 159 results after excluding 18 invalid votes. According to Table 4, the majority of respondents are men, accounting for $65.41 \%$. Besides, it is worth noting that the students of Information Technology dominantly participate in answering survey questions with $38,36 \%$, followed by International Business and Business Administration. Lastly, the figure for students of Course 14 takes up the most with $55.97 \%$, while Course 16 is the least.

\subsection{Reliability and Validity}

The reliability scale is assessed through Cronbach's Alpha coefficients to eliminate unsatisfactory variables. Variables with a corrected item-total correlation that is less than 0.3 will be excluded [40, 41, 42], while the Cronbach's Alpha coefficient which is greater than 0.6 will make the scale satisfactory [43]. The test results from Table 5 indicate that all of the education quality scales have the Cronbach's Alpha reliability coefficients of greater than 0.6, thus the scale selected in scientific research has statistical significance and meets the reliability requirement. These indicators vary from 0.8 to 1.0 , which demonstrates that the observable variables can express clearly the meanings of the factors. This high reliability can be explained by two main reasons: Firstly, the observational question is based on a specific theoretical basis and verified studies; Secondly, the sufficient numbers of observable variables approximately reflect the significance of factors. Besides, no variable has a corrected item-total correlation of less than 0.3. Thus, the results of testing the scale with Cronbach's Alpha prove that all scales are reliable and proper to be continuously included in EFA factor analysis.

Table 4. Sample distribution table

\begin{tabular}{|c|c|c|c|c|}
\hline \multicolumn{2}{|c|}{ Characteristics } & \multirow{2}{*}{$\begin{array}{c}\text { Number } \\
104 \\
\end{array}$} & \multirow{2}{*}{$\begin{array}{c}\text { Percentage } \\
65.41 \% \\
\end{array}$} & \multirow{2}{*}{$\begin{array}{c}\text { Cumulative percentage } \\
65.41 \% \\
\end{array}$} \\
\hline \multirow{4}{*}{ Sex } & Male & & & \\
\hline & Female & 50 & $31.45 \%$ & $96.86 \%$ \\
\hline & Others & 5 & $3.14 \%$ & $100.00 \%$ \\
\hline & Total & 159 & $100.00 \%$ & \\
\hline \multirow{8}{*}{ Faculty } & Information Technology & 61 & $38.36 \%$ & $38.36 \%$ \\
\hline & Business administration & 31 & $19.50 \%$ & $57.86 \%$ \\
\hline & International business & 50 & $31.45 \%$ & $89.31 \%$ \\
\hline & Hotel management & 7 & $4.40 \%$ & $93.71 \%$ \\
\hline & English/Japanese Language & 1 & $0.63 \%$ & $94.34 \%$ \\
\hline & Graphic design & 7 & $4.40 \%$ & $98.74 \%$ \\
\hline & Others & 2 & $1.26 \%$ & $100.00 \%$ \\
\hline & Total & 159 & $100.00 \%$ & \\
\hline \multirow{6}{*}{ Course } & 13 & 14 & $8.81 \%$ & $8.81 \%$ \\
\hline & 14 & 89 & $55.97 \%$ & $64.78 \%$ \\
\hline & 15 & 43 & $27.04 \%$ & $91.82 \%$ \\
\hline & 16 & 10 & $6.29 \%$ & $98.11 \%$ \\
\hline & Others & 3 & $1.89 \%$ & $100.00 \%$ \\
\hline & Total & 159 & $100.00 \%$ & \\
\hline
\end{tabular}


Exploratory Factor Analysis (EFA) is a quantitative analysis method used to reduce a collection of many interdependent measurement variables into a set of fewer variables (called factors), which are more meaningful but can still contain most of the information contents of the original variable set. Besides, the EFA method can be used to identify groups of criteria to evaluate the quality of educational services.

According to the research model, there are five components with 18 observable variables affecting SF. The results given by EFA determine that no variable would be removed, while the high KMO coefficient $(0.93)$ that meets the requirement of $0.5<\mathrm{KMO}<1$ indicates that the factor analysis is appropriate with the research data. Bartlett's test is 2234.736 with sig $=0.000<0.05$, which proves that the observable variables are correlated with each other, and the data used for analyzing the EFA factor are completely relevant (Table 5). With 18 observable variables, it is extracted into five factors with the total value of variance extracted of $78.031 \%(>50 \%)$, which is satisfactory, and these five factors can explain $78.031 \%$ of the variation of the observable variables.
Accordingly, all these five factors influence SF.

The outcomes of the rotated matrix display that the original five groups of factors are rearranged into five groups with different orders (Table 6). The first factor has 3 variables including IS1, IS2, and IS3, which is called "Infrastructure". The second factor has 4 variables including LT1, LT2, LT3, and LT4, which is "Lecturers". The third factor has 4 variables including EP1, EP2, EP3, and SQ4, which is called "Education Program". The fourth factor has 4 variables including SQ1, SQ2, SQ3, and IS4, which is named "Service Quality". The last factor has 3 variables TT1, TT2, and TT3, which has the name of "Tuition".

The results of EFA analysis for the dependent variable "Satisfaction" prove that the observable variables are steadily correlated to the analysis of the EFA factor through Bartlett's test with sig of $0(<0.05)$ and KMO of 0.805 ( $>0.5$ ) (Table 5). The results have one factor extracted with the Eigenvalue coefficient is 3.038 , and the total variance extracted is $75.96 \%$. The factor loadings of five observable variables all meet the requirement of greater than 0.5 .

Table 5. Data of the factors

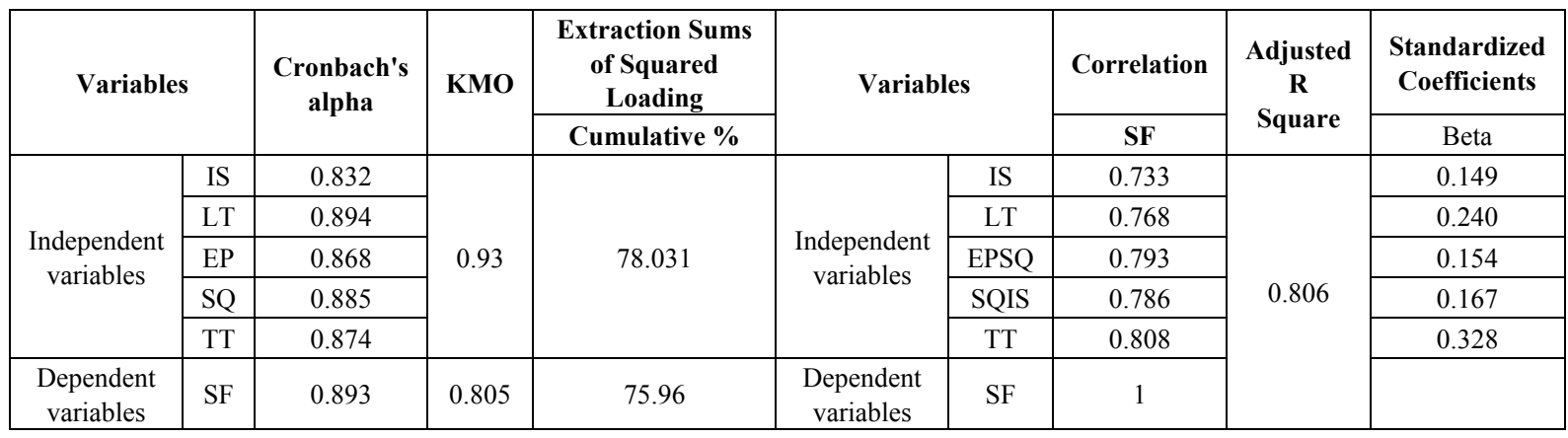

Table 6. Rotated component matrix

\begin{tabular}{|c|c|c|c|c|c|}
\hline \multicolumn{6}{|c|}{ Component } \\
\hline & 1 & 2 & 3 & 4 & 5 \\
\hline LT4 & 0.824 & & & & \\
\hline LT1 & 0.781 & & & & \\
\hline LT3 & 0.767 & & & & \\
\hline LT2 & 0.644 & & & & \\
\hline TT2 & & 0.740 & & & \\
\hline TT3 & & 0.733 & & & \\
\hline TT1 & & 0.714 & & & \\
\hline EP3 & & & 0.732 & & \\
\hline SQ4 & & & 0.703 & & \\
\hline EP2 & & & 0.714 & & \\
\hline EP1 & & & 0.598 & & \\
\hline SQ1 & & & & 0.790 & \\
\hline SQ2 & & & & 0.738 & \\
\hline SQ3 & & & & 0.600 & \\
\hline IS4 & & & & 0.526 & \\
\hline IS2 & & & & & 0.733 \\
\hline IS1 & & & & & 0.732 \\
\hline IS3 & & & & & 0.694 \\
\hline
\end{tabular}




\subsection{Regression Model}

The correlation results of the lecturer quality, tuition, education program, service quality and infrastructure with the student satisfaction levels are respectively 0.768 , $0.808,0.793,0.786,0.733$ (Table 5).

All the correlation coefficients are significantly less than $0.05 \%$ and the exact index is zero. Therefore, it can conclude that all of the independent variables have linear correlations with the dependent variable, which is the overall of student satisfaction. Furthermore, all variables present a positive correlation with student satisfaction. The variable having the highest value of correlation makes the maximum impact on student satisfaction, while the factor having the lowest value impacts the least. While tuition (TT) and student satisfaction (SF) have the highest Pearson correlation (0.808), the lowest correlation with the degree of student satisfaction is the infrastructure factor $(0.733)$.

To identify the most appropriate predictor of student satisfaction from the model, the linear regression analysis is performed with the student satisfaction level as the dependent variable. The analysis results show that the adjusted $\mathrm{R}$ square is 0.806 (table 5), suggesting that the model explains $80.6 \%$ of the variance in the measure of FPT student satisfaction levels with the education quality, which is explained by five independent variables. Moreover, the Durbin - Watson value is 2.110 , then no first-order series autocorrelation occurs.

The Anova is statistically notable of less than the 0.05 level. Thus, the model is trustworthy enough to predict the linear relationships between the independent variables and student satisfaction. According to Table 5, the regression coefficients of the LT, TT, EPSQ, SQIS, IS are 0.240, $0.328,0.154,0.167$ and 0.149 , respectively. EPSQ and SQIS are the new names for the variables after doing EFA. EPSQ is the combination of two variables EP and SQ along with SQIS is the mixture of SQ and IS. While analyzing data using SPSS software, the order of these variables has changed. Hence, the regression analysis result is:

$$
\begin{gathered}
S F=0.240 \times L T+0.328 \times T T+0.154 \times E P S Q \\
+0.167 \times S Q I S+0.149 \times I S
\end{gathered}
$$

The Sig value of the independent variables is less than 0.05 , which means these independent variables have a considerable significance on the dependent variable. Then, all the variables are remaining in the model. As a result, a unit change in the "Infrastructure" (IS), "Lecturers" (LT), "Education Program" (EP), "Service Quality" (SQ), and "Tuition" (TT) will lead to the variations in the student satisfaction at FPT University Da Nang by $0.149,0.240$, $0.154,0.167$, and 0.328 respectively. The order of the influence level from the strongest to least of the independent variables to the dependent variable $\mathrm{SF}$ is: TT $(0.328)>$ LT $(0.240)>\operatorname{SQIS}(0.167)>\operatorname{EPSQ}(0.154)>$ IS
$(0.149)$. The tuition factor is specified as the most substantial predictor affecting student satisfaction with the quality of education, while the infrastructure factor is the weakest value.

\section{Discussion}

Accordingly, the study determines five factors that are fundamental components affecting the level of student satisfaction at FPT University Da Nang, namely infrastructure, lecturers, education program, service quality, and tuition. They have had a notable influence on overall student satisfaction.

However, the regression results are consistent and have statistical significance, while the regression model is also compatible with the whole. According to the regression results, there is a statistically significant influence of tuition on the student satisfaction levels in comparison with other modeled variables. Besides, the student perceptions of the infrastructure, lecturers, education programs, service quality, and tuition aspects are positively correlated with overall student satisfaction.

\subsection{TT Impact Positively on SF}

The regression results determine that the tuition variable has the most influential impact on student satisfaction in terms of education quality. As the survey was carried out in the context of the COVID-19 pandemic, which has a tremendously adverse effect on the income of households, therefore students concern the most about tuition. Thus, FPT University Da Nang, as well as other private universities, requires proper strategies of tuition to meet students' financial ability with the aim of maintenance. The cost of courses should be affordably declined for diverse groups of students, such as students whose parents are working without a source of income due to the COVID-19.

\subsection{LT Impact Positively on SF}

The second influence is lecturers. Numerous students prefer FPT University Da Nang with the purpose of gaining a large amount of knowledge to broaden their horizons, and the lecturers play a crucial role as they are the ones who pave the way for students. As a result, universities necessitate acknowledging the lecturers' knowledge and abilities to take responsibility, along with their teaching methods that can help students effortlessly access. Furthermore, to recruit skillful teachers with a lot of experience, FPT University should have preferential policies to retain them, along with improving the quality of faculty by creating opportunities for teachers to study and research both at home and abroad. Besides, the assessment of the student's faculty should be stricter, and measures should be taken to deal with student complaints, 
yet enhance the teacher's quality and meet the requirements of the students.

\subsection{SQIS Impact Positively on SF}

Another factor that highly corresponds to student satisfaction is service quality. Service is one of the prominent activities at private universities like FPT. Thus, the school should develop the rapid and high-quality provision of the educational process and personal development programs. Besides, the administrators should listen to students' feedback and respond to student requests as fast as possible.

\subsection{EPSQ Impact Positively on SF}

The relationship of the education program with student satisfaction is notably substantial, as education activities play a notable role in the development of students. Thus, the school should enhance the learning process. Firstly, the training program should have coherent goals to meet the requirements of knowledge standards and practical skills, therefore the students can assure their desired job in the future. For example, the syllabus should be designed and balanced with the academic curriculum so that every student can get to learn beyond subjects. Furthermore, since there is a close bond between the school and students, the school should take notice of students' feedback about the school's actual shortcomings related to education, therefore the organization can advance the pessimistic sides.

\subsection{IS Impact Positively on SF}

The influence of the infrastructure on student satisfaction degrees is also analytically substantial, as it can affect the expected experience of students. Correspondingly, the university should offer a plan of periodic inspections annually to preserve and modernize the school's facilities, yet improve the students' learning process. Moreover, the academic libraries should always update the offline materials as well as the online data, and establish a quiet working area with up-to-date information to study. Lastly, the laboratory is necessary for students to have in-depth research, especially for their research passion.

\subsection{Compare to Previous Studies}

From the result, our research has proved the requisitely positive relationship between the overall education quality and student satisfaction, along with identifying 5 primary factors of education quality that fundamentally affect the students' satisfaction, respectively tuition, lecturers, serving ability, education program and facilities. Furthermore, this result is compatible with the finding of
Ha and Tran (2020). However, since the support team is excluded in that research, our research has finally affirmed the substantial connection between serving ability and student satisfaction. Besides, there is a lot of research that does not determine the relationship between several variables, such as lecturer factor in Pham (2016), serving quality in Hoang and Tran (2019). Nevertheless, our findings have established these variables' relationships.

Secondly, the significant importance of the education program and facilities has indeed been clarified through numerous researches. In Pham (2016) and Hoang and Tran (2019), the education program is the most influential factor, while in Tran (2016), Nguyen et. al. (2016), the factor that has the greatest effect is the facilities aspect. However, in our research, the education program and the facilities tend to have the least impact on student satisfaction compared to the other factors. Meanwhile, our research has determined that the lecturers' factor has the second most leading relationship with the dependent variable. Our finding corresponds with Tran (2016), Hoang and Tran (2019), Ha and Tran (2020), which also rates lecturers as the second most prominent force in their rankings. This demonstrates that the majority of students, regardless of public or private, are concerned about the teacher's performance.

Lastly, while the tuition factor is usually excluded from the model of the previous studies, our research has involved the tuition factor. There are two main reasons for this difference. First, private universities tend to not receive financial support from the government compared to public academics, while there is a lack of studies relating to private universities. Besides, tuition fees have become a source of concern for students as they have increased significantly over time, which has put tremendous pressure on students. Accordingly, our research has not only proved the relationship between the tuition factor and student satisfaction but also indicates that tuition tends to have the most influential impact on student satisfaction.

\section{Conclusions}

Education is a crucial branch of a country, as it helps to increase the number of high-quality employees engaging in the innovation of the country. Therefore, it is critical to keep on researching this field. Furthermore, since there is a substantial contrast between public academies and private universities that the private institutions are obliged to take care of their operating activities and appeal to the customers, investors for its survival, this contradiction has become not only the impediments but also the momentous burden for the private associations. Besides, FPT University has made a lot of efforts in improving the quality of education but has yet to receive remarkable recognition from the Vietnam education market. Therefore, the authors aspire to study more on the education quality of private institutions, especially at FPT University. 
Our research is mainly based on the theory of the Service-Product Bundle model of Jacqueline Douglas, Alex Douglas and Barry Barnes, along with the literature review of 10 papers studying student satisfaction with the education quality. Accordingly, the writers introduce the integrated framework for measuring the student satisfaction of private universities. By using the random sampling, Cronbach's Alpha, EFA, Regression and Correlations, our paper has identified five factors affecting the student satisfaction with the education quality of private universities. These five components involve infrastructure, lecturers, education program, service quality, and tuition. The regression results determine that the tuition variable has the most influence on student satisfaction, followed by lecturers, infrastructure, training program and service quality. The purpose of this paper is not only identifying the other distinctive variables affecting student satisfaction but also extraordinarily addressing this subject. Therefore, this research can help the principles of the private universities to have a distinct and comprehensive overview about the student satisfaction with the education quality, along with addressing problems and outlining the appropriate strategies, yet amend the universities' performance, firstly is the case of FPT University of Da Nang.

Because of the unavoidable shortcomings in the process of research, there are several indisputable limitations in our study. Firstly, since the sample size of the study is not too big (159 students), the results cannot be highly representative. Besides, there is a gender bias of the respondents, of which 104 males account for $65.41 \%$, while the number of participants at each grade also represents a large variation, with $55.97 \%$ of juniors and $6,29 \%$ of freshmen. Since the survey does not include all the numbers and classifications of students, the assessment results cannot be highly dependable. Consequently, it is essential to collect more survey samples that can cover all subjects for a more objective overview. Secondly, the above five independent variables explain $80.8 \%$ of the student satisfaction with the education quality of private universities, especially in FPT University. This outcome indicates that the remaining $19.2 \%$ are explained by other variables that are outside the model. It requires figuring out factors that are overlooked but can affect student satisfaction, from which several private universities will precisely perceive by which components that the satisfaction on the quality of training is affected. Furthermore, this research has not clearly shown the relationship between demographics, student satisfaction and the education program, which will be extended later for a more coherent and logical paper. Lastly, since the survey was carried on in the context of the COVID-19 pandemic, the participants might have contemporary responses that are not representative of all time. Therefore, the upcoming research about student satisfaction should be thoroughly conducted to discover the in-depth explanations behind the coefficients, along with carrying out the surveys in the period of stable conditions.

\section{Conflict of Interest}

The authors declare no conflicts of interest. The authors also declare that they have no known competing financial interests or personal relationships that could have appeared to influence the work reported in this paper.

\section{REFERENCES}

[1] Pham, T. L. (2016). Training Quality and Student Satisfaction: The Case of VNU University of Economics and Business. Vietnam National University Journal of Science: Economics and Business, 81-89.

[2] Garibaldi, P., Giavazzi, F., Ichino, A., \& Rettore, E. (2012). College cost and time to complete a degree: Evidence from tuition discontinuities. Review of Economics and Statistics, 94(3), 699-711.

[3] Bacila, M.F., Pop, M.C., Scridon, M.A. and Ciornea, R., 2014. Development of an instrument for measuring student satisfaction in business educational institutions. Amfiteatru Economic Journal, 16(37), pp.841-856.

[4] Vietnam News Tokyo (2018). Viet Nam wins four ASOCIO IT awards. Viet Nam News. https://vietnamnews.vn/econom y/469563/viet-nam-wins-four-asocio-it-awards.html.

[5] Gürel, E., \& Aydin, S. İ. (2016). Public Relations in Service Marketing. Journal of International Social Research, 9(45).

[6] Yin Cheong Cheng, W. M. (1997). Multi - models of quality in education. Quality Assurance in Education.

[7] Nguyen, D. T., \& Nguyen, T. M. T. (2009). Scientific research in Business Administration. Statistical Publishing House.

[8] Brochado, A. (2009). Comparing alternative instruments to measure service quality in higher education. Quality Assurance in Education.

[9] Harvey, L., \& Green, D. (1993). Defining quality. Assessment \& Evaluation in Higher Education, 18(1), 9-34..

[10] O'Neill, M. A., \& Palmer, A. (2004). Importance-performance analysis: a useful tool for directing continuous quality improvement in higher education. Quality Assurance in Education, p.42.

[11] Oliver, R. L. (1985). Disconfirmation Processes and Consumer Evaluations in Product Usage. Journal of Business Research.

[12] Tse, D. K., \& Wilton, P. C. (1988). Models of Consumer Satisfaction Formation: An Extension. Journal of Marketing Research.

[13] Kotler, P. \& Amstrong, G. (2012). Principles of Marketing, 14th Edition. New York: Pearson Educated, Limited. 
[14] Borden, V. M. (1995). Segmenting student markets with a student satisfaction and priorities survey. Research in Higher Education, 36(1), 73-88.

[15]Elliott, K. M., \& Shin, D. (2002). Student satisfaction: An alternative approach to assessing this important concept. Journal of Higher Education Policy and Management, 24(2), 197-209.

[16] Waugh, R. F. (2002). Academic staff perceptions of administrative quality at universities. Journal of Educational Administration.

[17] Buttle, F. (1996). SERVQUAL: review, critique, research agenda. European Journal of Marketing.

[18] Asubonteng, P., McCleary, K. J., \& Swan, J. E. (1996). SERVQUAL revisited: a critical review of service quality. Journal of Services Marketing.

[19] Pariseau, S. E., \& McDaniel, J. R. (1997). Assessing service quality in schools of business. International Journal of Quality \& Reliability Management.

[20] Douglas, J., Douglas, A., \& Barnes, B. (2006). Measuring student satisfaction at a UK university. Quality Assurance in Education.

[21] Weerasinghe, I. S., \& Fernando, R. L. (2017). Students' satisfaction in higher education. American Journal of Educational Research, 5(5), 533-539.

[22] Tran, H. A. (2016). Application of structural equation modeling to examine the relationship between educational quality and student feeling of satisfaction: a case study of the Faculty of Economic at VHU. Van Hien University Journal of Science.

[23] Hoang, T. H., \& Tran, T. T. H. (2019). A survey on the level of student satisfaction of the training quality of the accounting - auditing faculty at Banking Academy of Vietnam. Banking Science and Training Journal.

[24] Nguyen, T. L. (2006). Using the SERVPERF scale to assess the education quality of An Giang University. Scientific research report, An Giang University.

[25] Nguyen, T. B. C., \& Thai, T. B. C. (2013). Assessing the level of student satisfaction with the quality of training of the school of economics - business administration at Can Tho University a period of years 2012-2013. Science Journal of Can Tho University.

[26] Nguyen, T. N. X. (2018). Factors affecting student satisfaction with the quality of education quality at Tra Vinh University. Journal of Education.

[27] Nguyen, T. X. H., Nguyen, T. P., \& Vu, T. H. L. (2016). Factors affecting students' satisfaction with conditions of the facilities and services of Vietnam National University of
Forestry (VNUF). Journal of Science and Technology, 2016.

[28] Nguyen, Q. N. (2012). Factors affecting the level of student satisfaction with the quality of tourism training among universities in the Mekong Delta. Scientific Journal of Can Tho University.

[29] Vo, V. V. (2017). Factors affecting student satisfaction with the education quality: A survey from alumni of Nong Lam University. Ho Chi Minh City University of Education Journal of Science

[30]Ha, N. K. G., Tran, T. M. V. (2020). The satisfaction of students with the quality of basic science courses taught by Saigon Technology University. Viet Nam Trade and Industry Review.

[31] Haywood - Farmer, J. (1988). A Conceptual Model of Service Quality. International Journal of Operations \& Production Management.

[32] Price, I. F., Matzdorf, F., Smith, L., \& Agahi, H. (2003). The impact of facilities on student choice of university. Facilities.

[33] Baker, J. A. (1999). Teacher-student interaction in urban at-risk classrooms: Differential behavior, relationship quality, and student satisfaction with school. The Elementary School Journal, 100(1), 57-70

[34] ISCED. (2011). Educational programme. UNESCO.

[35] Smyth, E. (2008). The more, the better? Intensity of involvement in private tuition and examination performance. Taylor \& Francis Online.

[36] Meaning of tuition in English. (n.d.) (2021). Cambridge Dictionary.

https://dictionary.cambridge.org/dictionary/english/tuition.

[37] Sullivan, G. M., Artino Jr, A.R. (2013). Analyzing and Interpreting Data From Likert-Type Scales. Journal of Graduate Medical Education, 5(4), p.541.

[38] McIver, J. P., \& Carmines, E. G. (1981). Unidimensional scaling. SAGE Publication.

[39] Nemoto, T., \& Beglar, D. (2014). Developing Likert-scale questionnaires. In N. Sonda \& A. Krause (Eds.), JALT2013 Conference Proceedings. Tokyo: JALT.

[40] Nunnally, J. (1978). Psychometric Theory. New York: McGraw-Hill.

[41] Peterson, R. A. (1994). A Meta-Analysis of Cronbach's Coefficient Alpha. Journal of Consumer Research.

[42] Slater, S. F. (1995). Issues in Conducting Marketing Strategy Research. Journal of Strategic.

[43] Nunnally, J., \& Bernstein, I. (1994). Psychometric theory (3rd ed.). New York: McGraw-Hill. 